\section{A Rapid, Semiautomated Method for Apolipoprotein E Genotyping}

\author{
C. Guo, ${ }^{1,2}$ P. Marynen, ${ }^{1}$ and \\ J.J. Cassiman'
}

${ }^{1}$ Center for Human Genetics and

${ }^{2}$ Hypertension Unit, University of Leuven, Campus Gasthuisberg, O\&N6, B-3000 Leuven, Belgium
Apolipoprotein E (apo E), a single-chain polypeptide of 299 amino acids, is a protein component of lipoproteins playing a role in lipid metabolism through its interaction with the low-density lipoprotein (LDL) and chylomicron remnant receptors.

Three major isoforms, E2, E3, and E4, can be distinguished. Apo E4 differs from apo E3 at residue 112, where a cysteine is replaced by an arginine. In Apo E2, residue 158 , a cysteine is substituted for arginine. At the DNA level these polymorphisms can be detected by restriction fragment length polymorphisms after digestion with $\mathrm{HhaI}^{(1)}$ (Fig. 1). Apo E2 shows a significantly decreased binding activity ( $<2 \%$ compared with apo E3) to both LDL and chylomicron remnant receptors and is therefore catabolized more slowly than apo E3. Consequently, the accumulation of the triglyceride-rich very low-density lipoprotein (VLDL) remnants and a low level of LDL cholesterol is observed. Apo E2 is supposed to play a protective role against the development of atherosclerosis. Although the affinity of apo E4 for its receptors is indistinguishable from that of apo E3, its distribution differs from apo E3 and it is catabolized more rapidly than apo E3, leading to an accumulation of LDL cholesterol that could favor the development of atherosclerosis. ${ }^{(2,3)}$

As a consequence, apo E genotyping is of increasing importance in clinical practice to identify individuals at risk for cardiovascular diseases. Several methods have been developed for the genotyping of apo E. Some of these require two PCR steps followed by restriction digestion, ${ }^{(4,5)}$ whereas the PCR method with the amplification refractory mutation system primers needs four reactions for each sample. ${ }^{(6)}$ The method described by Hixson and Wenham includes one step of PCR amplification and restriction digestion. The restriction fragments are separated on an acrylamide gel and viewed under UV light after staining by ethidium bromide. ${ }^{(7)}$

To allow for the large-scale genotyping of apo E, a simple and rapid method was developed for the isolation of DNA from large numbers of whole blood samples using standard glass fiber filters. PCR in the presence of FITC-dUTP then allows for the nonradioactive detection of the different restriction fragments of apo E alleles using a fluorescent DNA sequencer.

\section{MATERIALS AND METHODS}

\section{Isolation of DNA from Whole Blood}

A Whatman GF/C 25-mm filter was put in a $1.5-\mathrm{ml}$ microcentrifuge tube with a pierced hole at the bottom. This assembly was then autoclaved and put in a second microcentrifuge tube in the rotor of a microcentrifuge. Cells were lysed by adding $300 \mu$ l of lysis buffer $[0.32 \mathrm{M}$ sucrose, $10 \mathrm{~mm}$ Tris- $\mathrm{HCl}$ (pH 7.5), 1\% Triton $\mathrm{X}-100,5 \mathrm{mM} \mathrm{MgCl}]^{(8)}$ to $100 \mu \mathrm{l}$ of whole blood. The mix was pipetted onto the top of the GF/C filter and spun briefly to collect the nuclei. Next, $200 \mu \mathrm{l}$ of $6 \mathrm{M} \mathrm{NaI}$ was added to the filter at room temperature for $5 \mathrm{~min}$ and spun for 20 sec. The filter was rinsed three times with $200 \mu$ l of wash buffer [70\% ethanol, $100 \mathrm{~mm} \mathrm{NaCl}, 10 \mathrm{~mm}$ Tris (pH 7.4)], and once with $20 \mu \mathrm{l}$ of $\mathrm{H}_{2} \mathrm{O}$, and spun for 20 sec after each washing. All washes were discarded. DNA was then eluted with

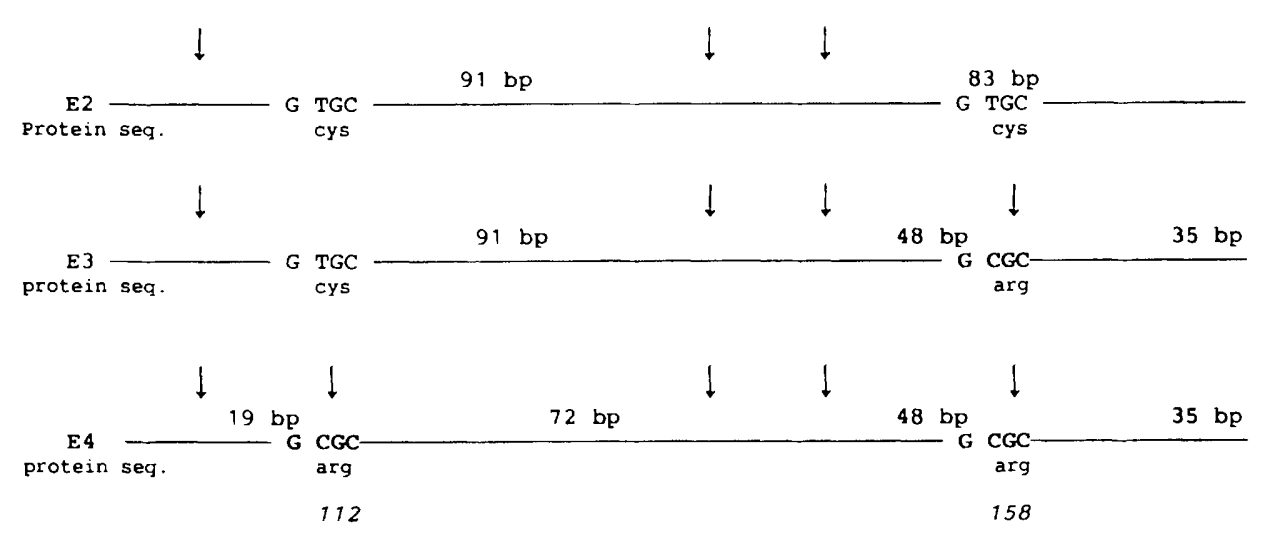

FICURE 1. HhaI restriction map of the different apo E alleles. Arrows show the Hhal cleavage sites. The fragment sizes generated by Hhal are also indicated. 
$40 \mu \mathrm{l}$ of $\mathrm{H}_{2} \mathrm{O}$ and collected in a new microcentrifuge tube.

\section{PCR Amplification and Genotyping of Apo E}

Twenty microliters of eluted DNA was added directly to the PCR mix $[10 \mathrm{~mm}$ Tris- $\mathrm{HCl}(\mathrm{pH} \mathrm{8.3),} 50 \mathrm{~mm} \mathrm{KCl}, 1.5 \mathrm{~mm}$ $\mathrm{MgCl}_{2}, 0.01 \%$ gelatin, $50 \mu \mathrm{M}$ of each dNTP, $0.5 \mu \mathrm{M}$ of FITC-dUTP, 25 pmoles of each primer [5'-ACAGAATTCGCCCCCGGCCTGGTACAC-3'; 5'-TAAGCTTGGCACGGCTGTCCAAGGA- ${ }^{\prime},{ }^{\prime 7)} \quad 10 \%$ of DMSO, and 2.5 units of Taq polymerase] in a total volume of $100 \mu$ l. After denaturing the DNA by heating the reaction mix to $94^{\circ} \mathrm{C}$ for $5 \mathrm{~min}, 30$ cycles of PCR were performed with denaturation at $94^{\circ} \mathrm{C}$ for $30 \mathrm{sec}$, annealing at $58^{\circ} \mathrm{C}$ for $30 \mathrm{sec}$, and extension at $70^{\circ} \mathrm{C}$ for $30 \mathrm{sec}$. Ten microliters of the PCR product was digested with 3 units of $\mathrm{HhaI}$ at $37^{\circ} \mathrm{C}$ for $1 \mathrm{hr}$, mixed with an equal volume of stop solution (deionized formamide with 5 $\mathrm{ng} / \mathrm{ml}$ of dextran blue), and denatured for $3 \mathrm{~min}$ at $85^{\circ} \mathrm{C}$. Six microliters of the sample was then loaded onto a $7 \%$ polyacrylamide gel containing $7 \mathrm{M}$ urea and $0.6 \times \mathrm{TBE}$, and run in a fluorescent DNA sequencer (A.L.F. Pharmacia) at $1500 \mathrm{~V}$, $38 \mathrm{~mA}, 34 \mathrm{~W}$ with the gel temperature at $40^{\circ} \mathrm{C}$ for 2 hr. Forty samples can be loaded simultaneously onto a gel that can be reused twice.

\section{RESULTS AND DISCUSSION}

The DNA purification method is based on the binding of DNA to glass fibers in the presence of a high concentration of $\mathrm{NaI} .{ }^{(9)}$ The lysis step allows for the removal of the majority of plasma and erythrocyte proteins while the nuclei are retained by the GF/C filter. All steps are performed by spinning the different solutions through the assembly. Twentyfour samples can therefore be extracted simultaneously in a conventional microcentrifuge rotor. The DNA has a molec- ular mass of $>12 \mathrm{~kb}$, and, typically, $\sim 2$ $\mu \mathrm{g}$ are obtained of a quality sufficient for PCR amplification. FITC-dUTP is added to the PCR mixture. In our hands, the incorporation of FITC-dUTP by Taq DNA polymerase is efficient to label the PCR fragments. The incorporation of FITC-dUTP thus allows for the easy detection of all different restriction fragments, without requiring an additional enzymatic step, for example, the ligation of an FITC-labeled adaptor, or the addition of an FITC-ddUTP with terminal deoxynucleotide transferase.

The results obtained for the six apo E genotypes are shown in Figure 2. The peaks from right to left represent the 91-, 83-, 72-, and 48-bp fragments, respectively. The sizes of the fragments were confirmed by running a sequencing reaction in the same gel. A mixture of samples with known genotypes can be used as a marker.

Although not strictly necessary, denaturing gels were used because this exper-

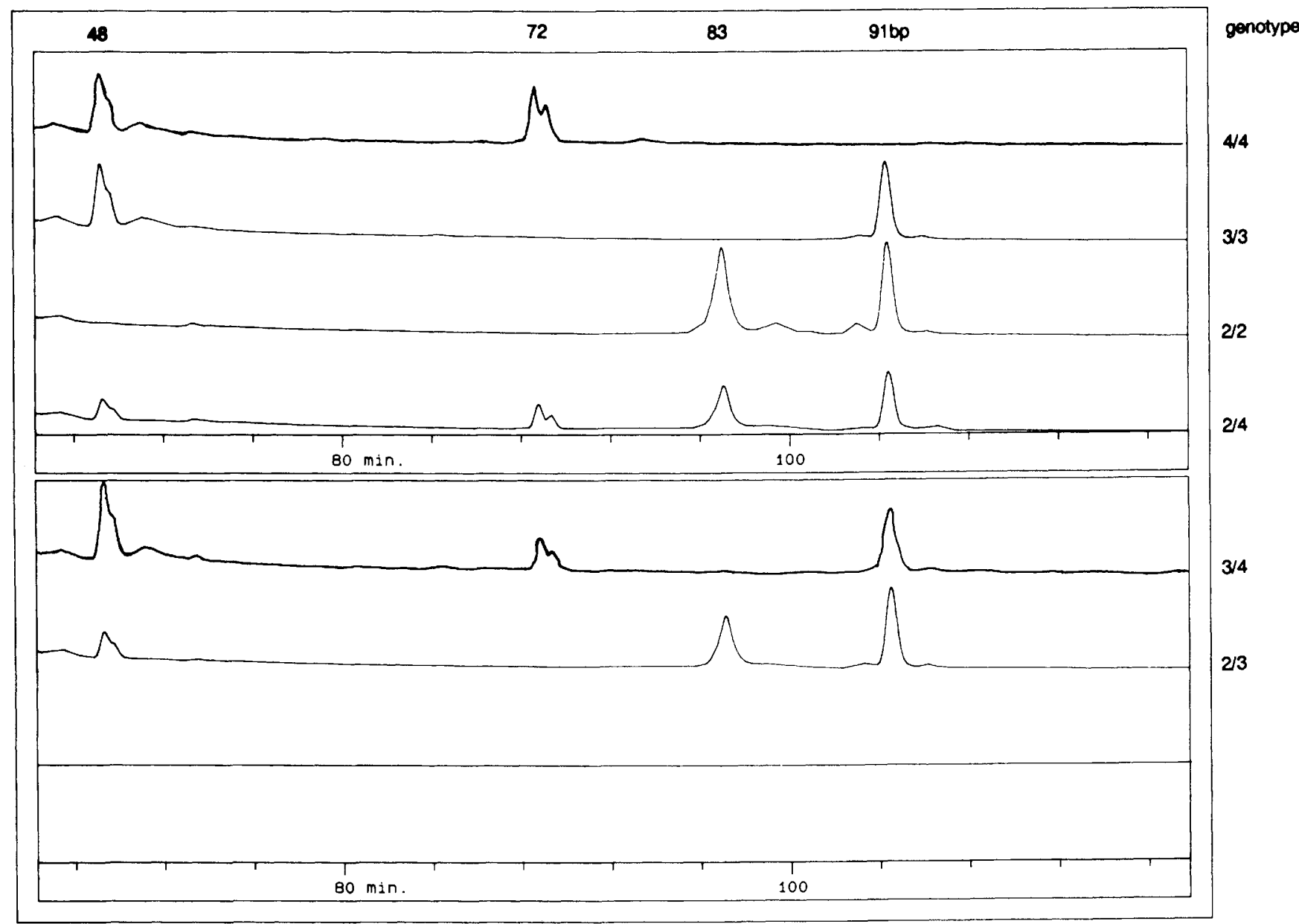

FIGURE 2. Fluorescent apo E genotyping with the A.L.F. sequencer. The six possible genotypes are shown. The sizes of the fragments are indicated in bp above the peaks. 
imental setup yields a higher resolution compared with nondenaturing gels. Under these circumstances the 48-bp peak always shows a shoulder, whereas the 72 bp fragment systematically yields a double signal. These artifacts, which could be attributable to secondary structures reminiscent of compression problems observed during sequencing or to differences in FITC-dUTP incorporation, are completely reproducible and are, although not fully understood, useful as an additional identification of different fragments. The simultaneous analysis of 40 samples and the possibility to reuse the polyacrylamide gel twice allows for a high output of samples.

In conclusion, a procedure is presented for the genotyping of apo $E$ in large numbers of whole blood samples. The procedure avoids the use of proteinase $\mathrm{K}$, phenol, radioactivity, and ethidium bromide and should be applicable for the genotyping of a variety of different loci.

\section{ACKNOWLEDGMENTS}

Peter Marynen is a Bevoegdverklaard Navorser of the Nationaal Fonds voor Wetenschappelijk Onderzoek. This work was supported by grant 3.0025.92 of the Nationaal Fonds voor Wetenschappelijk Onderzoek and by a grant Geconcerteerde Acties from the Belgian Government and the Interuniversity Network for Fundamental Research sponsored by the Belgian Government (1991-1995).

\section{REFERENCES}

1. Wallis, S.C., S. Rogne, L. Gill, A. Markham, M. Edge, D. Woods, R. Willianson, and S. Humphries. 1983. The isolation of cDNA clones for human apolipoprotein $\mathrm{E}$ and the detection of apoE RNA in hepatic and extra-hepatic tissues. EMBO I. 2: 2369-2373.

2. Mahley, R.W. 1988. Apolipoprotein E: Cholesterol transport protein with expanding role in cell biology. Science 240: 622-630.

3. Davignon, J., R.E. Gregg, and C.F. Sing. 1988. Apolipoprotein E polymorphism and atherosclerosis. Arteriosclerosis 8: $1-21$.

4. Kontula, K., K. Aalto-Setälä, T. Kuusi, L. Hämäläinen, and A.C. Syvänen. 1990. Apolipoprotein E polymorphism determined by restriction enzyme analysis of DNA amplified by polymerase chain reaction: Convenient alternative to phenotyping by isoelectric focusing. Clin. Chem. 36: 2087-2092.
5. Green, E.K., S.C. Bain, P.J.R. Day, A.H. Barnett, F. Charleson, A.F. Jones, and M.R. Walker. 1991. Detection of human apolipoprotein E3, E2, and E4 genotypes by an allele-specific oligonucleotide primed polymerase chain reaction assay: Development and validation. Clin. Chem. 37: 1263-1268.

6. Wenham, P.R., C.R. Newton, and W.H. Price. 1991. Analysis of apolipoprotein E genotypes by the amplification refractory mutation system. Clin. Chem. 37: 241244.

7. Hixson, J.E. and D.T. Vernier. 1990. Restriction isotyping of human apolipoprotein $E$ by gene amplification and cleavage with Hhal. J. Lipid Res. 31: 545-548.

8. Buffone, G.J. and G.J. Darlinton. 1985. Isolation of DNA from biological specimens without extraction with phenol. Clin. Chem. 31: 164-165.

9. Vogelstein, B. and D. Gillespie. 1979. Preparative and analytical purification of DNA from agarose. Proc. Natl. Acad. Sci. 76: 615-619. 


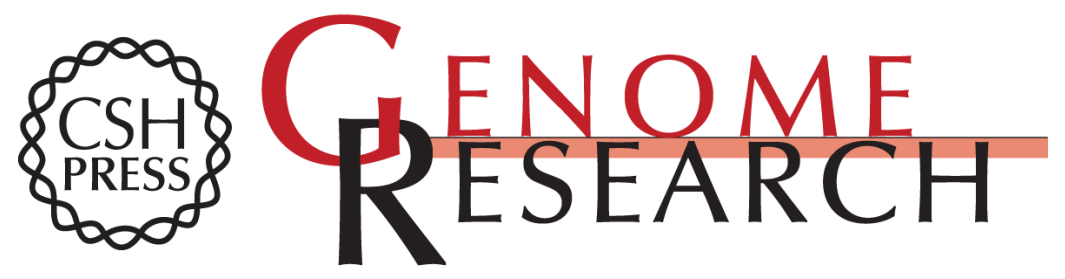

\section{A rapid, semiautomated method for apolipoprotein E genotyping.}

C Guo, P Marynen and J J Cassiman

Genome Res. 1993 2: 348-350

Access the most recent version at doi:10.1101/gr.2.4.348

References This article cites 9 articles, 7 of which can be accessed free at:

http://genome.cshlp.org/content/2/4/348.full.html\#ref-list-1

\section{License}

Email Alerting Receive free email alerts when new articles cite this article - sign up in the box at the Service top right corner of the article or click here.

\section{Affordable, Accurate Sequencing.}

To subscribe to Genome Research go to: https://genome.cshlp.org/subscriptions 